\title{
State Citizenship, EU Citizenship and Freedom of Movement
}

\author{
Richard Bellamy
}

\section{Introduction}

I agree with the two key premises of Floris de Witte's 'kick off': namely, that 1) freedom of movement lies at the core of EU citizenship and is worth defending as such, and 2) that many of the attacks on it are at best misinformed, misguided and mistaken, at worst malign, mendacious, and motivated by prejudice and xenophobia.

However, I disagree with much of what he says in support of these positions. I think he confuses the moral case for some form of cosmopolitanism and the empirical reinforcement this gets in an interdependent world, on the one hand, with an argument for a fully fledged political and legal cosmopolitanism that looks to the ultimate demise of nation states as a necessary condition for justice, on the other. The first may offer normative and empirical support for a supranational Union of states along the lines of the EU, in which there is a status such as Union citizenship that offers free movement between the component polities. However, that need not imply a version of the second involving a teleological account of the EU's development, such as de Witte offers, whereby individuals must cease to be members of nation states; democracy becomes in some way constrained by, or even substitutable by, a given conception of justice; and we need no longer conceive ourselves as members of a community of fate. What I want to suggest in this comment is that one can accept a broadly cosmopolitan moral and empirical case for free movement within the EU as both normatively compelling and of practical benefit, while disputing all three of his arguments for this position and maintaining the very statist perspective on each of the three issues that he seeks to challenge.

Let me start by briefly setting out (space constraints mean I cannot here defend, though I have attempted to do so elsewhere ${ }^{1}$ ) what might be called

\footnotetext{
1 Among other pieces, see Bellamy, R. (2013), 'An Ever Closer Union of Peoples: Republican Intergovernmentalism, Demoi-cracy and Representation in the EU', Journal of European Integration 35 (5): 499-516; (2015),
} 
a cosmopolitan statist perspective on the EU. I shall then deploy this perspective to comment on Floris de Witte's three arguments, noting in each case how free movement can be defended while stopping short of the view he advocates.

\section{Cosmopolitan statism, EU citizenship and freedom of movement}

On the account I adopt, the most normatively appealing and empirically plausible way of conceiving the EU is as a republic of democratic nation states. The argument is broadly Kantian, tweaked to accommodate contemporary concerns and conditions. It is both statist and cosmopolitan, and orientated around the value of non-domination. It is statist in arguing that to institute justice among individuals who reasonably disagree about its nature and application requires the establishment of a sovereign authority to govern the relations of those who share a social space. Yet if that authority is to be non-dominating and not itself a source of injustice, it must be under the equal influence and control of those to whom it applies. Therefore, justice implies the establishment of both a state and a democratic regime within it. Just relations can only pertain among citizens. However, in an interconnected world it becomes possible not only for states and their citizens to dominate other states and their citizens, both directly and indirectly, but also for various non-state agents and agencies, such as corporations and terrorist groups, to do so. That possibility increases when not all states operate democratically, with such non-democratic states not only dominating their own citizens, but also more likely to seek to dominate the citizens of other states too and to provide a haven for non-state agents and agencies to do so as well. Meanwhile, citizens of all states have various reasons to move freely between states- some to escape dominating or failing regimes, others to trade, find employment and for leisure, among other motives. As a result, states have good cause to cooperate and establish supranational legal and political structures to prevent their mutual domination, help them support non-dominating regimes in states where they do not as yet exist or are under threat, tackle domination from other non-state sources, and to facilitate the free movement of citizens between these states in ways that avoid

\footnotetext{
'Between Cosmopolis and Community: Justice and Legitimacy in A European Union of Peoples', in S. Tierney (ed.), Nationalism and Globalisation: New Settings, New Challenges, 207-232. Oxford: Hart; and (2016) (with S. Kröger), 'Beyond a Constraining Dissensus: The Role of National Parliaments in Domesticating and Normalising the Politicization of European Integration', Comparative European Politics 14 (2): 131-153.
} 
discrimination or domination, either of or by them. My claim is that the EU can be regarded as the closest we have to such a republican system of states at present.

Of course, I am not suggesting either that the EU perfectly meets the criteria of such a structure or that all the actors involved by any means conceive it in these terms. ${ }^{2}$ I merely contend that it is a plausible way of conceiving it and one that has normative appeal as a guide to how it should and could develop. On this view, a commitment to the role of democratic states as offering a context for non-dominating relations among citizens requires as a matter of consistency that states act towards other states and their citizens on the basis of certain cosmopolitan norms, not least through establishing structures such as the Council of Europe and the EU that seek to reduce non-domination between, within and across states in the various ways mentioned above. In this regard, the current support of certain Conservative politicians in Britain for Brexit and/or withdrawal from the ECHR must be regarded as either incoherent - at odds with their professed desire to defend the very idea of democratic statehood, or insincere - either done for political advantage or because they are not that attached to democracy in the first place.

I make these points to indicate how one can be opposed to the populist nationalist rhetoric of those critical of the very idea of the EU and of free movement within it, without necessarily being opposed to the idea of democratic statehood. On the contrary, one can regard the EU as existing to support democratic statehood in a variety of ways rather than as supplanting and substituting for it. From this perspective, the linkage of Union citizenship to member state citizenship is not a transitionary feature destined to whither away but inherent to its very nature. Its purpose is not to supplant but to supplement member state citizenship in two main ways: first, it allows free movement between states in ways that involve showing equal concern and respect to the citizenship regimes of both the host state and that state of origin; second, it gives citizens a direct say in the supranational structures to ensure they show them equal concern and respect as citizens of distinct member states. As we shall see, this is very different to the characterisation that Floris de Witte offers.

2 For a critique of current EU economic and monetary policies from this perspective, see Bellamy, R. \& A. Weale (2015), 'Political Legitimacy and European Monetary Union: Contracts, Constitutionalism and the Normative Logic of Two-Level Games', Journal of European Public Policy 22 (2): 257-274. 


\section{De Witte's three arguments}

De Witte's first argument favouring free movement is that it emancipates the individual from the nation state. He offers rather different instances of this emancipation. One of his examples, that of an LGBT couple denied recognition in their country of birth, concerns a denial of human rights within a given state. The others, such as the retired teacher from Middlesbrough seeking to enjoy her pension in Lanzarote, relate to various personal choices that will be facilitated through freedom of movement between states, some involving more significant interests than others. He claims that emphasis on nationality only provides public recognition to individuals on the basis of a single dimension that ignores or even suppresses the other dimensions of people's lives - as he puts it, in a statement I find extraordinary, 'the nation state's mode of social integration reduces the incredibly complex individual to a one-dimensional being.' This hyperbole grossly mischaracterises the role of nationality within the public cultures of the member states, all of which are constitutional democracies. It is not as if the retired teacher is obliged by UK law to only spend her pension on holidaying in an approved British seaside resort with suitably grey weather and wearing a hat displaying the Union Jack. The legal systems of most member states uphold rights to as diverse a range of life style choices as are to be found across the EU, even if all states fall short in certain respects, some more egregiously than others. Yet all these rights require a political infrastructure to determine and enforce them. This infrastructure involves citizens of any polity in a complex set of mutual obligations, that in the case of securing many rights such as pensions - require a degree of solidarity among them. Emancipation from these sorts of bonds constitutes a form of free-riding that is ultimately self-defeating for all but a privileged few. For these very bonds make the rights individuals claim possible in the first place. ${ }^{3}$ The retired teacher would not wish to go to Lanzarote if such an infrastructure was not in place that ensured a system of property rights sufficient to allow her holiday home to be built and uphold her civil rights to personal security once there, and would not have a pension enabling her to do so in the first place if she had not worked under a similar regime in the UK. Any system of free movement, therefore, has to be such that it respects and upholds the two systems of citizenship rights that make her movement from one to the other possible in the first place.

3 I have criticised a somewhat similar argument to de Witte's by Dimitry Kochenov in Bellamy, R. (2015), 'A Duty Free Europe? What's Wrong with Kochenov's Account of EU Citizenship Rights', European Law Review 21 (4): $558-565$. 
His second argument for free movement, as a recalibration of justice and democracy, is in this respect more nuanced in that it appears, initially at least, to recognize that there is a need for reciprocity both between citizenship regimes and among those who participate within any one of them. As it happens, I agree with him that there is no evidence that the UK would be justified in applying an 'emergency brake'. But none of what he says here seems to justify the statement that freedom of movement serves 'to recalibrate questions of justice and democracy in a more appropriate manner', a position that is hardly addressed at all. At best, it suggests that appropriate mechanisms do not exist for a constructive democratic dialogue that allows for a clear discussion of how we might balance reciprocity between citizenship regimes and reciprocity within them in an equitable and sustainable way. So far that has been a matter for the CJEU looking at particular cases, on the one hand, and intergovernmental agreements, on the other. Yet both seem somewhat ad hoc and insufficiently connected to citizens as a body, which perhaps explains the general alienation from the decisions of both

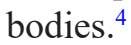

His third argument restates the first in a neo-Habermasian manner as separating 'nation' and 'state', because EU citizenship 'lacks the ties to a homogenous political 'community of fate' that perpetuate significant exclusionary practices'. Again the element of truth in this statement gets lost through exaggeration. Floris de Witte suggests that national citizenship within the member states 'is linked to a 'community of fate' that reflects certain ethno-cultural ideas of a homogenous community'. As I observed above, though, what Habermas called 'constitutional patriotism' forms the norm across the EU. All the member states have citizenship regimes involving elements of 'ius soli' as well as 'ius sanguinis' and most have citizenries with considerable cultural diversity and mixed blood. Sadly, and worryingly, there are parties of the extreme right everywhere that are motivated by 'ethno-cultural ideas of a homogenous community', and in a very few countries these parties are in government. But such sentiments are not intrinsic to the very idea of a nation state. EU citizenship has no tie to any notion of nationality because that is not its function. It exists to facilitate internationality and to some degree multi-nationality, but not the demise of any sense of nationality whatsoever. As I noted, a sense of political solidarity is important for the upholding of rights that we can only possess as members

4 On the 'democratic disconnect' in EU policy making, see Bellamy, R. \& S. Kröger (2016), 'The Politicization of European Integration: National Parliaments and the Democratic Disconnect', Comparative European Politics 14 (2): 125-130. 
of a political community. The role that EU citizenship and free movement should play is in heightening our awareness of and respect for such solidarity within all the states of the Union.

\section{Conclusion}

As I said at the beginning, I fully agree with Floris de Witte's concern at the attacks on the EU currently coming from the populist right, a challenge epitomized by, but unfortunately not restricted to, the Brexit campaign in the UK. However, I doubt that the best way to answer their misleading rhetoric is to make rhetorical counter-claims that are the mirror image of theirs. Rather, it is to show that their views are largely without foundation and that far from undermining national citizenship, EU citizenship and free movement defend it in the context of the normative and empirical challenges of an inter-dependent world.

Open Access This chapter is licensed under the terms of the Creative Commons Attribution 4.0 International License (http://creativecommons.org/licenses/by/4.0/), which permits use, sharing, adaptation, distribution and reproduction in any medium or format, as long as you give appropriate credit to the original author(s) and the source, provide a link to the Creative Commons license and indicate if changes were made.

The images or other third party material in this chapter are included in the chapter's Creative Commons license, unless indicated otherwise in a credit line to the material. If material is not included in the chapter's Creative Commons license and your intended use is not permitted by statutory regulation or exceeds the permitted use, you will need to obtain permission directly from the copyright holder. 